\title{
Erratum to: Study of cosmogenic activation in copper for rare event search experiments
}

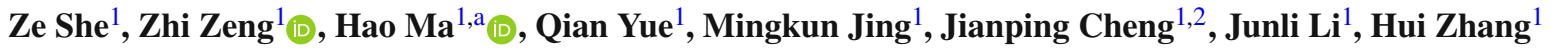 \\ ${ }^{1}$ Key Laboratory of Particle and Radiation Imaging (Ministry of Education) and Department of Engineering Physics, Tsinghua University, \\ Beijing 100084, China \\ ${ }^{2}$ College of Nuclear Science and Technology, Beijing Normal University, Beijing 100875, China
}

Published online: 13 December 2021

(C) The Author(s) 2021

\section{Erratum to: Eur. Phys. J. C (2021) 81:1041 \\ https://doi.org/10.1140/epjc/s10052-021-09827-w}

In this article the caption of figure 4 contained a typesetting mistake. The correct caption reads:

Fig. 4 Simulated cosmogenic background spectra in 0 2.8 MeV region from copper components of germanium detectors for CDEX-100 experiment

The publisher apologizes for the inconvenience caused. The original article has been corrected.

Open Access This article is licensed under a Creative Commons Attribution 4.0 International License, which permits use, sharing, adaptation, distribution and reproduction in any medium or format, as long as you give appropriate credit to the original author(s) and the source, provide a link to the Creative Commons licence, and indicate if changes were made. The images or other third party material in this article are included in the article's Creative Commons licence, unless indicated otherwise in a credit line to the material. If material is not included in the article's Creative Commons licence and your intended use is not permitted by statutory regulation or exceeds the permitted use, you will need to obtain permission directly from the copyright holder. To view a copy of this licence, visit http://creativecomm ons.org/licenses/by/4.0/.

Funded by $\mathrm{SCOAP}^{3}$.

The original article can be found online at https://doi.org/10.1140/ epjc/s10052-021-09827-w.

a e-mail: mahao@mail.tsinghua.edu.cn (corresponding author) 